\title{
TREČIOSIOS UNIVERSITETŲ MISIJOS POVEIKIS MOKSLO ŽINIŲ SKLAIDAI UNIVERSITETINĖSE STUDIJOSE
}

\author{
Marija Stonkienè \\ Vilniaus universitetas \\ Saulètekio al. 9, I rūmai LT-10222 Vilnius, Lietuva \\ Tel. 8-5 2366119 \\ El. paštas: marija.stonkiene@kf.vu.lt \\ Renata Matkevičienè \\ Vilniaus universitetas \\ Sauletekio al. 9, I rūmai LT-10222 Vilnius, Lietuva \\ Tel. 8-5 2366119 \\ El. paštas: renata.matkeviciene@kf.vu.lt
}

Pateikta 2014 m. spalio 18 d., parengta spausdinti 2014 m. gruodžio 10 d.

doi:10.13165/SMS-14-6-3-10

Anotacija. Straipsnyje aptariamas žiniu ekonomikos plètros poveikis universitetu veiklai, teigiant, kad produkto statuso suteikimas žinioms keičia universitetų veiklos sąlygas, reikšmina universitetu indèlị $\mathfrak{i}$ ekonomikos augima ir socialinę plètrą. Kintančios veiklos sąlygos pirmiausiai skatina universitetus tapti žiniu tinklo dalimi, inovaciju agentais, aktyvinti bendradarbiavima su pramone. Universitetu versluma, ju veiklos rezultatu pritaikomuma skatina ir mažèjančios ju veiklos finansavimo viešaisiais ištekliais galimybès, auganti konkurencija žinių sklaidos srityje. Visa tai pagrindžia idejją, kad universitetu veiklos kaita paskatino su tradicinemis universitetu funkcijomis (mokslo tyrimais ir studijomis) susijusios mokslo žiniu sklaidos pokyčius - tradicine mokslo žinių sklaidą keičia, papildo mokslo rezultatu sklaidos per jų pritaikyma procesai. Moks- 
lininkai, vertindami universitetuose vykstančius pokyčius, teigia besiformuojant trečiaja universitetu misiją.

Trečiosios universitetu misijos koncepcija grindžiama universitetu verslumu bei universitetu teikiamos praktines naudos reikšminimu. Trečiosios universitetu misijos teorinè prieiga argumentuoja Europos aukštojo mokslo sistemose vykstančius pokyčius, siejamus su tradicinés europinés aukštojo mokslo orientacijos ị visuomenés socialines, kultūrines reikmes, aukštojo mokslo kaip valstybès vykdomos socialinès politikos, užtikrinamos viešaisiais ištekliais, suvokties kaita. Šią kaitą lemia rinkos ideologija, neoliberalizmu argumentuojamas naujosios viešosios vadybos taikymas aukštojo mokslo sistemai. Naujoji viešoji vadyba siejama su universitetu veiklos rezultatu praktinio pritaikomumo reikšmès augimu, orientavimusi ne tik $j$ visuomenés socialinius poreikius, bet ir i universitetu visuomenei teikiama ekonominę bei kita socialinę naudą, tenkinamus rinkos poreikius.

Straipsnyje teigiama, kad $2009 \mathrm{~m}$. Lietuvos nacionaliné aukštojo mokslo sistemos reforma, pakeitusi aukštojo mokslo sistemos finansavima, paskatinusi universitetu konkurenciją, sudariusi sąlygas universitetu verslumui, taip pat yra grindžiama praktinio aukštojo mokslo sistemos veiklos rezultatu (tiek mokslo tyrimu, tiek studiju srityse) naudojimo svarbos reikšminimu. Siekiant įvertinti, ar 2009 m. Lietuvos nacionaliné aukštojo mokslo sistemos reforma turèjo toki poveikị universitetu studiju misijos vykdymui, straipsnyje keliamas probleminis klausimas - ar po 2009 m. Lietuvos nacionalinès aukštojo mokslo reformos pakito reikalavimai nacionalinèms studiju programoms, reikšminant studiju metu teikiamu aukštojo mokslo žiniu praktinį pritaikomuma, atliepti rinkos poreikiams. I ši problemini klausima atsakoma igyvendinant straipsnio tiksla - nustatyti norminiu reikalavimu nacionalinems studiju programoms kaitą, ¿̇vykusia po 2009 m. nacionalinès aukštojo mokslo reformos.

Norminiu dokumentu kokybines turinio analizés ir lyginamuoju metodais buvo nustatyta, kad po $2009 \mathrm{~m}$. Lietuvos nacionalinés aukštojo mokslo reformos atnaujintuose norminiuose reikalavimuose studiju programoms (ju kürimui, vertinimui, akreditavimui) yra ženklus visuomenes intereso ir darbdaviu įtraukimo į studiju procesa ịtvirtinimas. Atliktas tyrimas parode akivaizdžiai padidèjusị dèmesị studiju veiklos rezultatu praktiniam pritaikomumui po $2009 \mathrm{~m}$. nacionalinès aukštojo mokslo reformos. Tyrimas taip pat atskleide, kad šiuo metu Lietuvoje ketinamu vykdyti ar jau igyvendinamu studiju programu aprašams ir studiju programu vertinimui ir akreditavimui keliami kiek skirtingi norminiai reikalavimai, susije su universitetu studiju misijos igyvendinimo praktines naudos aspektu. Vertinant ir akredituojant studiju programas yra dar labiau reikšminamas studiju rezultatu praktinio pritaikomumo poreikis - norminiuose reikalavimuose studiju programu vertinimui ir akreditavimui dar labiau išryškinamas socialiniu dalininku vaidmuo, santykis su darbo rinka ir profesine sritimi yra nurodomas ne tik studiju programos tikslo ir numatomu studiju rezultatu apibrèžtyje, bet ir studiju eigos apraše. 
Reikšminiai žodžiai: universitetas, mokslo žinių sklaida, trečioji universitetu misija, 2009 m. nacionalinè aukštojo mokslo reforma, studijos, studiju programos, norminiai reikalavimai.

\section{Ivadas}

Tradiciškai universitetų veikla siejama su dviem pagrindinemis jų funkcijomis mokymu ir mokslo tyrimais. P. Chattertonas ir J. Goddardas pastebi, kad šios universitetų funkcijos vykdomos jų sukauptų žinių bazės pagrindu ${ }^{1}$. Mokslininkai atkreipia dèmesi ji kintančias universitetų funkcijas. Ši kaita siejama su tuo, kad šiandien universitetai suvokiami kaip svarbiausi regioninès plètros, grịstos inovacijomis, subjek$\operatorname{tai}^{2}$, o universitetų intelektiniai ištekliai laikomi esminiais teritorinio inovatyvumo veiksniais $^{3}$, universitetų veiklai keliamas didesnès atsakomybės visuomenei reikalavimas, atlieptis ekonominès, kultūrinès, socialinès pažangos poreikiams ${ }^{4}$.

Mokslininkai aplinkos skatinamą universitetų veiklos kaitą apibūdina pasitelkdami trečiosios universitetų misijos koncepciją. Trečioji universitetų misija yra suvokiama kaip praktinès naudos visuomenei teikimas, apimantis tiek inovacini, tiek socialinị aktyvumą, tiek universitetų verslumą, siejamus ir su moksliniais tyrimais, ir su mokymo veikla. Pastebima, kad kintanti aukštojo mokslo institucijų veiklos terpé, sukèlusi pokyčius tradicinèje universitetų veikloje, paskatino ir su tradicinèmis universitetų funkcijomis susijusios mokslo žinių sklaidos kaitą. Tradicinę mokslo žinių sklaidą keičia, papildo mokslo rezultatų sklaidos per jų pritaikymą procesai, t. y. mokslo žinių sklaida (kaip ir jų kūrimas) kinta dèl to, kad mokslo žinių sklaidoje (kaip ir kūrime) reikšminama tiek ekonominė jų nauda, tiek jų praktinė nauda visuomenei, t. y. mokslo žinių (mokslo tyrimų rezultatų) praktinis pritaikomumas.

Mokslo tiriamojoje veikloje mokslo tyrimų rezultatų pritaikomumas formuoja naujas universitetų veiklos sritis, susijusias su mokslo tyrimų rezultatų komercinimu - patentavimu, licencijavimu, spin-off imonių steigimu ir pan. Analizuojant universitetinių studijų, kaip savito mokslo žinių sklaidos proceso kaitą, atkreipiamas dèmesys ị tai, kad naudos visuomenei paradigma yra neatsiejama nuo šios universitetų funkcijos. Universitetinių studijų kaip viešojo gèrio suvoktis ir vertinimas yra

1 Chatterton, P.; Goddard, J. The response of higher education institutions to regional needs. European Journal of Education. 2000, 35(4): 484.

2 Landabaso, M.; Oughton, C.; Morgan, K. Learning regions in europe: theory, policy and practice through the ris experience. 3rd International Conference on Technology and Innovation Policy: Global knowledge Partnerships, Creating value forthe 21 Century. [interaktyvus]. Austin, USA (August 30 -September 2) 1999 [žiūrèta 2014-07-07]. <http://www.deu.edu.tr/ userweb/sedef.akgungor/dosyalar/learning\%20region2.pdf>

3 Chatterton, P.; Goddard, J. The response of HEIs to regional needs. Iš: Economic Geography of Higher Education. NY: Routledge, 2003, p. 19-42.

4 Benneworth, P.; Jongbloed, B. W. Who matters to universities? A stakeholder perspective on humanities, arts and social sciences valorisation. Higher Education. 2010, 59(5): 567-588. 
ịprastas (ir itin aiškiai išreikštas kontinentinėje Europoje). Tačiau pokyčiai, vystantys aukštajame moksle, skatina mokslo žinių sklaidos kaitos procesus ir šioje universitetų veiklos srityje, t. y. ir šioje srityje taip pat stebimos (vienokiu ar kitokiu mastu) universitetų verslumo raiškos (pvz., universitetinès studijos, finansuojamos studijuojančiojo namų ūkio léšomis, su pramonès subjektais rengiamos ir jų finansuojamos studijų programos; valstybès finansuojamos tikslinės studijų vietos ir pan.). Mokslo žinių pritaikomumo reikšminimas keičia ir mokymo organizavimą, mokymo procesą (pvz., praktika tampa pramonès atstovų dalyvavimas studijų procese, formuojamos tikslinės besimokančiųjų grupès, studijų rezultatų vertinime ịskaitomos ir vertinamos patirtinès kompetencijos ir kt.).

Lietuvos nacionalinės aukštojo mokslo sistemos atliepties kintančioms aukštojo mokslo sistemos veiklos aplinkybėms (mažejančioms valstybinio finansavimo galimybèms, masiškèjančiam aukštajam mokslui ir kt.) užtikrinti 2009 m. buvo pradèta nacionalinès aukštojo mokslo reforma. Vykstantys aukštojo mokslo sistemos finansavimo pokyčiai (quasi rinkos aukštajame moksle kūrimas ịvedant mišrias arba alternatyvias aukštojo mokslo finansavimo formas, pasitelkiant naujosios viešosios vadybos instrumentus ir kt.) leidžia formuluoti prielaidą, kad nacionalinejje aukštojo mokslo sistemoje universitetų veikloje reikšminamas jų verslumas, pabrěžiama praktinio aukštojo mokslo sistemos veiklos rezultatų (tiek mokslo tyrimų, tiek studijų srityse) naudojimo svarba. 2009 m. Lietuvos aukštojo mokslo reforma tyrinejjama R. Želvio ${ }^{5}$, I. Dzemydos ir J. Babravičiauss ${ }^{6}$, N. Pileičikienès ir K. Pukelio ${ }^{7}$, D. Serafino ir J. Ruževičiaus ${ }^{8}$ ir kt. mokslininkų darbuose bei Mokslo ir studiju stebėsenos ir analizès centro (MOSTA) atliekamuose tyrimuose. Tačiau moksliniuose tyrimuose nebuvo analizuojamas nacionalinès aukštojo mokslo reformos, ịvedusios rinkos (quasi rinkos) santykius aukštajame moksle poveikis studijų turiniui, universitetinèms studijų programoms.

Aptartų mokslinių tyrimų analizė pagrindžia šio straipsnio naujumą ir iškelia šio straipsnio tikslą - dokumentų turinio kokybinès analizès ir lyginamuoju metodais nustatyti norminių reikalavimų nacionalinėms studijų programoms kaitą, i̇vykusią po $2009 \mathrm{~m}$. nacionalinès aukštojo mokslo reformos. Straipsnyje keliamas probleminis klausimas - ar kaip nacionalinès aukštojo mokslo reformos išdava pakito reikalavimai nacionalinèms studijų programoms, reikšminant studijų metu teikiamų aukštojo mokslo žinių praktinį pritaikomumą, atlieptị rinkos poreikiams. Ar nacionalinèje aukštojo mokslo sistemoje keliami studijų praktinio pritaikomumo reikalavimai, nustatoma analizuojant norminius reikalavimus nacionalinèms studijų programoms

5 Želvys, R. Studento krepšelis: pirmieji eksperimento rezultatai. Pedagogika. 2009, 96: 9-14.

6 Dzemyda, I.; Babravičius, J. Naujosios viešosios vadybos elementai ir „studijų krepšelio“ modelio diegimas Lietuvoje. Viešoji politika ir administravimas. 2012, 11 (2): 260-271.

7 Pileičikienè, N.; Pukelis, K. Aukštųjų mokyklų absolventų išsiugdytų bendrųjų kompetentingumų ir darbo rinkos poreikių atitiktis. Aukštojo mokslo kokybė. 2012, 9: 140-168. 
bei studijų programų ekspertiniam vertinimui. Studiju programos - tai tam tikros krypties studijų turinio, metodų ir materialiụjų priemonių, studijoms pasitelkiamo akademinio ir profesinio personalo visuma ir jos aprašymas, studijų programos tikslingumui atskleisti būtinas ne tik jos tikslo, rezultatų, bet ir darbo rinkos poreikio atskleidimas. Todèl norminių reikalavimų nacionalinèms studijų programoms bei studijų programų ekspertiniam vertinimui analizè, pristatoma šiame straipsnyje, leidžia nustatyti, ar $2009 \mathrm{~m}$. aukštojo mokslo reforma siejama su valstybès reikšminamu studijų programų atliepimu darbo rinkos poreikiams, studijų programų teikiamų žinių pritaikomumu ir ar tai yra atspindima studijų programų kūrimą, vertinimą bei akreditavimą reglamentuojančiuose dokumentuose. Atlikti norminių studijų programų kūrimo ir vertinimo reikalavimų tyrimą paskatino ir Valstybinio audito ataskaitoje, vertinančioje, kaip organizuojamas studiju programų rengimas ir vertinimas, išsakyti teiginiai, kad ,dalis studiju programu parengiamos nepakankamai pagrindus poreiki, <...> nesudaromos pakankamos salygos parengti rinkos poreikius ir studentu lükesčius atitinkančias studiju programas" ${ }^{\text {"g }}$ bei teiginiai, išsakyti nacionalines studiju programas 2010-2013 m. vertinusių ekspertų apibendrintose išvadose. Vertindami technologijos mokslų srities studijų programas, ekspertai pastebejo, kad „vis dažniau darbdaviu grupiu darbas ir pasiūlymai nèra formalizuojami $<\ldots>$ planuojant studiju programu ateities strategija socialiniai partneriai turi büti labiau ịtraukti ir jų indèlis labiau matomas ${ }^{" 10}$. Vertinant biomedicinos mokslų srityje vykdomas programas pastebèta, kad šios programos „yra orientuotos i taikomaja veikla - pasižymi praktine orientacija ir pagristos visuomenés poreikiais" ${ }^{11}$. Tačiau ši praktinè orientacija, ekspertų manymu, „turètu büti grindžiama periodiškai atliekama darbo rinkos poreikiu analize ${ }^{\text {"12 }}$. Atlikę socialinių mokslų srityje vykdomų studijų programų analizę ekspertai pastebejo, kad „tam tikrose programose egzistuoja problema dèl ju pagristumo rinkos poreikiais" ${ }^{\prime 13}$.

Tyrimas atliekamas taikant kokybinès dokumentų turinio analizės ir lyginamąji metodus. Universitetai turédami autonomiją gali rengti ir tvirtinti studijų programas, kurios atitinka norminių teisis aktų reikalavimus; įstatymu taip pat numatyta, kad aukštosiose mokyklose gali būti vykdomos tik akredituotos studijų programos. Todèl, atliekant norminių reikalavimų studijų programoms analizę, vertinami tiek norminiai reikalavimai studijų programoms, tiek norminiai reikalavimai studiju

9 Kaip organizuojamas studijų programų rengimas ir vertinimas: Lietuvos Respublikos valstybès kontrole valstybinio audito ataskaita [interaktyvus]. 2012 m. spalio 1 d. Nr. VA-P-50-1-12, p. 4 [žiūrèta 2014-10-14]. <www.vkontrole.lt/failas.aspx?id=2733>.

10 Technologijos mokslų srities apžvalga. (2014) SKVC [interaktyvus]. [žiūrèta 2014-10-16]. $<$ http://www.skvc.lt/files/SVS/technologijos_mokslu_apzvalga.pdf >.

11 Biomedicinos mokslų srities apžvalga. (2014) SKVC [interaktyvus]. [žiūrèta 2014-10-16]. $<$ http://www.skvc.lt/files/SVS/biomedicinos_mokslu_apzvalga.pdf $>$.

12 Ibid.

13 Socialinių mokslų srities apžvalga. (2014) SKVC [interaktyvus]. [žiūrèta 2014-10-16]. <http:// www.skvc.lt/files/SVS/socialiniu_mokslu_apzvalga.pdf> 
programų akreditavimui ir ekspertiniam vertinimui. Šių dokumentų analizès pjūvis nacionaliniuose norminiuose dokumentuose keliami reikalavimai studijų programų kūrimui ir vertinimui, susiję su darbo rinkos poreikiais. Tiriama šių reikalavimų kaita - analizuojami dokumentai, reglamentuojantys studijų programų aprašą, teikiamą siekiant studiju programos akreditacijos, taip pat nurodantys reikalavimus studijų programos ekspertiniam vertinimui iki $2009 \mathrm{~m}$. nacionalinès studijų reformos ir po šios reformos, siekiant nustatyti, ar yra, ar pakito studijų programų teikiamų žinių ir gebejimų praktinio pritaikomumo reikalavimai, santykio su darbdaviais, kitais socialiniais dalininkais apibrežtis. Analizuojami ir vertinami norminiuose dokumentuose įtvirtinami reikalavimai pagal esmines studijų programų vertinimo kategorijas: programos tikslai ir numatomi studiju rezultatai; programos sandara; personalas; materialieji ištekliai; studijų eiga ir vertinimas; programos vadyba.

Pirmojoje straipsnio dalyje, aptarus trečiosios universitetų misijos koncepciją, yra įžvelgiami šios koncepcijos universitetų veiklos rezultatų praktinio pritaikomumo idejomis aiškintini universitetų misijų igyvendinimo pokyčiai. Antrojoje straipsnio dalyje analizuojama nacionalineje aukštojo mokslo sistemoje studijų programoms keliamų reikalavimų, susijusių su studijose reikšminamais rinkos poreikių ar kitais studiju metu teikiamų mokslo žinių praktinio pritaikomumo aspektais, kaita po $2009 \mathrm{~m}$. nacionalinès aukštojo mokslo reformos.

\section{Trečioji universitetų misija: mokslo žinių praktinio pritaikomumo poreikis ir universitetų misijų igyvendinimo kaita}

Mokslo literatūra, aptarianti universitetų funkcijų kaitą, gali būti skirstoma ị kelis teminius blokus, reikšmingus universitetų funkcijų kaitos ištirtumo analizei. Mokslininkų darbuose daug dèmesio skiriama universitetų veiklos konteksto kaitos aptarimui ${ }^{14}$, universitetų funkcijų kaitai - tiek trečiosios universitetų misijos radimuisi, tiek kitų tradicinių universitetų funkcijų kaitai ${ }^{15}$. Analizuojant pokyčius daug dèmesio skiriama mokslo tyrimų rezultatų sklaidai, jų komercinimui ${ }^{16}$,

14 Maskell, D.; Robinson, I. The New Idea of a University. Imprint academic, 2002; De Zilwa, D. Using entrepreneurial activitiesas a means of survival: Investigating the processes used by Australian universities to diversify their revenue streams. HigherEducation. 2005, 50(3): 387411 ir kt.

15 Hannon, P. D. Why ist he Entrepreneurial University Important? Journal of Innovation Management. 2013, 1(2): 10-17; Guerrero, M.; Urbano, D. The development of anentrepreneurial university. The Journal of Technology Transfer. 2012, 37(1): 43-74 ir kt.

16 Leydesdorff, L.; Meyer, M. The Triple Helix of University-Industry-Government Relations: Introduction to the Topical Issue. Scientometrics. 2003, 58(2): 191-203; Mittelstadt, A.; Cerri, F. Fostering Entrepreneurship for Innovation. OECD STI Working Paper 2008/5. Technology Incubators: Nurturing Small Firms. Paris: OECD Publishing ir kt., 2008. 
universitetų ir pramonès sąveikai ${ }^{17}$. Analizuodami universitetų mokymo funkcijoje vykstančius pokyčius mokslininkai aptaria aukštojo mokslo tarptautiškumo didejimą (internacionalizaciją) ${ }^{18}$, aukštojo mokslo masiškejjimą ${ }^{19}$, dèl pramonès subjektų įsitraukties vykstančią studijų proceso kaitą ${ }^{20}$, universitetų absolventų parengimą / pasirengimą globaliai darbo rinkai ${ }^{21}$, tiria ir universitetų reagavimą $\mathfrak{x}$ socialinius ir ekonominius regionų ir vietos plètros poreikius ${ }^{22}$.

Mokslininkų teigimu, esminị poveikị universitetų veiklos kaitai turèjo žinių ekonomikos radimasis, sureikšminęs žinių vertę, suteikęs žinioms produkto statusą. Tai lèmé universitetų indèlio ị ekonomikos augimą ir socialinę plètrą ịvertinimą, pirmiausiai dèmesị skiriant praktiniam mokslo tyrimų rezultatų pritaikomumui. Reaguojant ị aplinkos pokyčius, augančią konkurenciją žinių sklaidoje (žinių visuomenèje atsiranda nauji mokslo tyrimų vykdytojai, žinių kūrèjai), universitetai keičia savo veiklą, tapdami svarbia žinių tinklo dalimi, transformuodamiesi ir tapdami versliais universitetais. Žinių ekonomikos radimasis skatina pramonès ir universitetų bendradarbiavimą, pramonès subjektai ịsilieja ị universitetų veiklą, universitetai tampa pramonès aplinkos veiksniais, dalyvauja pramonės veikloje. Universitetú verslumo augimą skatino ir kintančios valstybių, tradiciškai finansavusių aukštojo mokslo sistemą viešaisiais finansiniais ištekliais, mažèjančios finansavimo galimybès (masiškejjant aukštajam mokslui, mažèja valstybių galimybės viešaisiais finansais užtikrinti deramą aukštojo mokslo sistemos funkcionavimą). Šiame naujame kontekste

17 Owen-Smith, J.; Riccaboni, M.; Pammolli, F.; Powell, W. W. A comparison of US and European university-industry relations in the life sciences. Management science. 2002, 48(1): 24-43; Charles, D. Universities as key knowledge infrastructures in regional innovation systems. Innovation: th eEuropean journal of social science research. 2006, 19(1): 117-130 ir kt.

18 Altbach, P. G. The complex roles of universities in the period of globalization. Higher education in the world. 2008, 3: 2-10; Altbach, P. G.; Knight, J. The internationalization of higher education: Motivations and realities. Journal of studiesin International education. 2007, 11(34): $290-305$ ir kt.

19 Shattock, M. European universities for entrepreneurship: Their role in the Europe of knowledge the theoretical context. Higher Education Management and Policy. 2005, 17(3): 13-27 ir kt.

20 Ramakrishnan, K.; Yasin, N. M. Higher learning institution-industry collaboration: A necessity to improve teaching and learning process. ComputerScienceandEducation (ICCSE), 20116 th InternationalConference. 2011, p. 1445-1449 ir kt.

21 Leitch, S. Prosperity for all in the global economy-world class skills: final report. The Stationery Office, 2006; Archer, W.; Davison, J. Graduate employability: What do employers think and want? The Council for Industry and Higher Education (CIHE) [interaktyvus]. London, 2008 [žiūrèta 2014-07-19]. <www.cihe-uk.com/docs/PUBS/0802Grademployability.pdf> ir kt.

22 Arbo, P.; Benneworth, P. Understanding the regional contribution of higher education institutions: A literature review. A research report prepared fort he OECD Institutional Management in Higher Education Programme ,The contribution of higher education to regional development“. OECD Paris, 2008; Gibb, A.; Haskins, G.; Robertson, I. Leading the entrepreneurial university: Meeting the entrepreneurial development need soft higher education institutions. Universities in Change, Springer New York, 2013, p. 9-45 ir kt. 
susiformavo trečiosios universitetų misijos koncepcija, grindžiama universitetų sąveika su pramone ir visuomene ${ }^{23}$.

Mokslinès literatūros analizė leidžia pastebèti, kad trečiosios universitetų misijos koncepcija turi kelias skirtingas interpretacijas, lemiamas finansinès, moksliniu tyrimu rezultatų komercinimo ir socialinés aprépties prieigos. Finansinè prieiga trečiosios universitetų misijos radimąsi sieja su universitetų veiklos finansavimo diversifikavimu. B. Clarkas trečiosios universitetų misijos radimąsi įžvelgia pajamų šaltinių ịvairovèje: pirmasis šaltinis - viešosios lěšos, universitetų gaunamos studijoms vykdyti, antrasis pajamų šaltinis - lèšos, gaunamos iš mokslinių tyrimų institucijų, remiant mokslinius tyrimus, ir trečiasis lěšų šaltinis - visos kitos lešos, kurios gaunamos iš ịvairių kitų šaltinių (iš fondų, namų ūkių įmokos ir pan.) ${ }^{24}$. Pastebima, kad finansinę prieigą tikslinga pasitelkti apibendrintai vertinant universitetų trečiosios misijos skverbti, tačiau ši prieiga nerodo trečiosios misijos plètotès lygmens (universitetų veiklos finansavimas yra glaudžiai susijęs su universitetų valdymo struktūra, valstybès keliamais tikslais aukštojo mokslo sistemai, valstybès prioritetais plètojant aukštojo mokslo sistemą ir kt.). Su šia prieiga ideologiniu lygmeniu siejasi trečiosios universitetų misijos kaip mokslinių tyrimų rezultatų komercinimo samprata. Mokslinių tyrimų rezultatų komercinimas svarbus universitetų ištekliams išnaudoti, tiek universitetų veiklos regiono inovatyvumui didinti, pozityviai tiek ekonominei, tiek socialinei raidai užtikrinti. Trečiąją universitetų misiją siejant su mokslo tyrimų rezultatų komercinimu pasitelkiama verslaus universiteto koncepcija ${ }^{25}$. Pastebima, kad verslus universitetas siekia ekonominès naudos komercindamas mokslo tyrimu rezultatus (patentuodamas, perduodamas know-how, kurdamas spin-off imones ir pan.), t. y. pats suteikdamas jiems pramoninị pritaikomumą.

Trečiosios universitetų misijos kaip universitetų socialinio aktyvumo suvoktis siejama su universitetų dalyvavimu gerinant socialinę apreptị ir yra pagrindžiama atskirų visuomenių, valstybių universitetams keliamais tikslais. Šiai trečiosios universitetų misijos idèjos interpretacijai yra būdingas dèmesio perkèlimas nuo „technologijų perdavimo“, kuris remiasi universitetų moksline tiriamąja veikla, ị ",mokslo žinių perdavimą", grindžiamą tiek mokslo tiriamąja, tiek mokymo veikla. Ši trečiosios universitetų misijos suvoktis argumentuojama ir tokia universitetų veikla, kuri nekuria papildomų finansinių išteklių, tačiau yra itin aktuali visuomenei, vietos bendruomenei, regionui. Tokiu būdu universitetams keliami platesni praktinès naudos visuomenei teikimo reikalavimai - siekiama, kad universitetai dalyvautų teikdami

23 Arbo, P.; Benneworth, P. Understanding the regional contribution of higher education institutions: A literature review. A research report prepared for the OECD Institutional Management in Higher Education Programme „The contribution of higher education to regional development“. OECD Paris, 2008.

24 Clark, B. R. Creating Entrepreneuria Universities: Organizational Pathways of Transformation. Issues in Higher Education. NY, 1998.

25 Hannon, P. D. Why is the Entrepreneurial University Important? Journal of Innovation Management, supra note 15, p. 10-17; Guerrero, M.; Urbano, D., supra note 15, p. 43-74 ir kt. 
naudą ne tik ekonominèse, bet ir socialinèse, kultūrinėse, aplinkos apsaugos ir kitose visuomenès gyvenimo sferose. Universitetai turètų teikti naudą visuomenei dalyvaudami gerinant gyvenimo kokybę, didinant viešųjų paslaugų veiksmingumą ${ }^{26}$. Iš kitos pusès, $\mathfrak{i}$ kintantị universitetų vaidmenị žvelgiant plačiau, itin pabrěžiama, kad universitetų veikla turi atliepti regionų poreikius, t. y. universitetai naudą visuomenei turi teikti veikdami kaip esminiai veikejjai regioninių inovacijų plètotės sistemoje. Vienas iš svarbių tokios naudos visuomenei aspektų yra regioninę plètrą užtikrinančių kvalifikuotų specialistų rengimas. M. Breznitzas ir M. Feldmanas teigia, kad žmogiškojo kapitalo formavimas yra reikšminga „švietimo vertès grandis“ “27. Universitetinių studijų svarba praktiniame mokslo žinių pritaikymo kontekste suvokiama kaip regiono konkurencingumo didinimo veiksnys - M. Fernández-Esquinas ir H. Pinto mano, kad universitetai yra itin svarbūs formuojant žmogiškųjų išteklių politiką, jie sudaro galimybes nukreipti tiek absolventus, tek mokslininkus $\mathfrak{i}$ atitinkamus ekonomikos sektorius, didinant jų konkurencingumą, kuriant naujas įmones ir naujus verslo branduolius $^{28}$. Mokslininkai teigia, kad trečioji universitetų misija formuoja pirmąją ir antrąją misijas, jas nukreipia ${ }^{29}$.

Trečiosios universitetų misijos idejjos stebimos ir ES vykstančioje universitetų valdymo sistemos kaitoje - E. Butkus ir G. Vilūnas, apibendrindami 2006 m. Kopenhagoje įvykusiame Europos Komisijos Švietimo ir kultūros generalinio direktorato suorganizuotame seminare išsakytas įžvalgas pastebi, kad ES vykstanti universitetu valdymo sistemos kaita „stiprina universitety orientacija i praktines visuomenés reikmes, studijų ir moksliniu tyrimų rezultatu komercializavima, socialine atsakomybę ir konkurencinguma “30. Taigi tiek mokslineje doktrinoje, tiek politiniu lygiu yra pripažistamas augantis rinkos poreikių poveikis universitetų veikloje. Tai skatina palaipsnę universitetų valdymo sistemos vertybinių orientacijų kaitą - universitetų valdymo procesuose vis daugiau ima lemti ne tik vyriausybès ir net ne pačių aukštojo mokslo isstaigų, bet vartotojų - studentų, verslo, plačiosios visuomenès - interesai, universitetai skatinami teikti vis daugiau praktiškai apčiuopiamos naudos mažesniais kaštais;

26 Howard, J.; Sharma, A. Universities'Third Mission: Community Engagement, B-HERT (Business/ Higher Education Round Table) Position Paper [interaktyvus]. June 2006, 11: 3 [žiūrèta 201410-09]. <http://www.bhert.com/publications/position-papers/B-HERTPositionPaper11.pdf>.

27 Breznitz, S. M.; Feldman, M. P. The larger role of the university in economic development: introduction to the special issue. The Journal of Technology Transfer. 2012, 37(2): 135-138.

28 Fernández-Esquinas, M.; Pinto, H. The role of the university in Urban regeneration: reframing the analytical approach [interaktyvus]. 2011 [žiūrèta 2014-10-16]. < http://works.bepress.com/ manuel_fernandez_esquinas/37>.

29 Polt, W.; Gassler, H.; Schibany, A.; Rammer, C.; Schartinger, D. Benchmarking industryscience relations: the role of framework conditions. Science and public policy. 2001, 28(4): 247-258.

30 Butkus, E.; Viliūnas, G. Universitetų valdymo reforma Europos šalyse. Mokslas ir technika. 2006, 5: 4-5. 
finansuotojai - tiek valstybė, tiek privatūs rèmėjai - nori, kad aukštosios mokyklos būtų ne tik akivaizdžiau atskaitingos, bet ir labiau orientuotųsi i jų praktines reikmes ${ }^{31}$.

Atkreipiamas dėmesys, kad trečiosios universitetų misijos koncepcija sietina su požiūrio ị aukštojo mokslo vertès, jo misijos suvokimo Europoje kaitą. Tradiciné aukštojo mokslo orientacija ị visuomenès socialines, kultūrines reikmes, aukštojo mokslo kaip valstybės vykdomos socialinès politikos, užtikrinamos viešaisiais ištekliais, suvoktis Europoje, t. y. aukštojo mokslo kaip viešosios gèrybės samprata, grindžiama tiek klasikine universitetine laisvojo ugdymo tradicija, tiek valstybės dalyvavimu organizuojant ir teikiant aukštąj mokslą, yra keičiama rinkos ideologijos, neoliberalizmu argumentuojamos naujosios viešosios vadybos taikymo aukštojo mokslo sistemai. Tai reiškia, kad universitetų veiklos finansavimo išteklių paieška, sietina su universitetų veiklos rezultatų praktinio pritaikomumo reikšmès augimu, orientavimasis ne tiek $\mathfrak{i}$ visuomenès socialinius poreikius, kiek ị ekonominę universitetų visuomenei teikiamą naudą tampa europinio aukštojo mokslo kasdienybe.

Europos Komisijos užsakymu atlikti Europos Sąjungos valstybių aukštojo mokslo sistemų tyrimai (Progress in higher education reform across Europe: Governance Reform ir Progress in higher education reform across Europe: Funding reform) atskleidè, kad nuo 1995 m. daugumoje Europos Sąjungos valstybių buvo pradètos aukštojo mokslo reformos ${ }^{32}$. Aukštojo mokslo reforma vyko ir Lietuvoje. Kaip esminès 2009 m. Lietuvos aukštojo mokslo reformą paskatinusios priežastys Lietuvos aukštojo mokslo reformos dokumentuose nurodomos dvi priežastys: poreikis užtikrinti studijų kokybę ir nepakankamas studijų finansavimas valstybès biudžeto léšomis ${ }^{33}$. „Mokslo ir studijų būklès 2009 m. apžvalgoje“ teigiama, kad reformą ígyvendinančiu Lietuvos Respublikos mokslo ir studijų i̇statymu inicijuojami pokyčiai lema valstybès sąveikos su aukštojo mokslo institucijomis pokyčius - Lietuvoje aukštojo mokslo sistemoje ịdiegiamas naujosios viešosios vadybos modelis, kurio didžiausias poveikis siejamas su pasikeitusiu aukštojo mokslo finansavimu, aukštojo mokslo instituciju valdymu bei šių institucijų ilgalaikio turto nuosavybe ir valdymu ${ }^{34}$. Mokslinio tyrimo „Lietuvos aukštojo mokslo (LAM) sistemos pletra 2007-2012 m.: konkurencingumas ir finansavimo modelis" ataskaitoje nurodoma, kad Lietuvos aukštojo mokslo sistemos gyvavimo prielaidos yra ,rinkos principu ir valstybinio reguliavimo santykio op-

31 Butkus, E.; Viliūnas, G., supra note 30.

32 Progress in higher education reform across Europe. Governance reform. Volume 1: executive summary and main report. (2010) Center for Higher Education Policy Studies. Unassigned, [interaktyvus]. [žiūrèta 2014-03-17]. <http://ec.europa.eu/education/higher-education/doc/ governance/sum_en.pdf>, Progress in higher education reform across Europe. Funding reform. Volume 1: Executive summary and main report. (2010) Center for Higher Education Policy Studies.Unassigned [interaktyvus]. [žiūrèta 2014-03-17]. <http://ec.europa.eu/education/ higher-education/doc/funding/sum_en.pdf >.

33 Mokslo ir studijų reforma: pristatymas (2008) [interaktyvus]. [žiūrèta 2014-07-17]. <http:// www.smm.lt/msr/docs/Informacija_mokslo_ir_studiju_reforma.pdf $>$.

34 Mokslo ir studijų būklès apžvalga (2009) [interaktyvus]. [žiūrèta 2014-07-17]. <http://www. mosta.lt/images/documents/stebesena/bukles_apzvalga/mokslas_ir_studijos_2009.pdf 
timizavimas; rinkos principu ir visuomeninio intereso derinimas; <... > ${ }^{\text {"35 }}$. Tai leidžia teigti, jog nacionalinèje aukštojo mokslo sistemoje greta aukštojo mokslo kaip viešojo gèrio suvokties formuojasi ir rinkos prieiga, sietina su aukštųjų mokyklų veiklos rezultatų praktinio pritaikomumo poreikiu, kuris laikytinas esminiu trečiosios universitetų misijos koncepcijos skiriamuoju požymiu. Ar ši prielaida teisinga universitetams igyvendinant studijų organizavimo ir igyvendinimo veiklas siekiama nustatyti analizuojant norminių reikalavimų Lietuvoje teikiamoms studijų programoms kaitą po 2009 m. aukštojo mokslo reformos.

\section{Trečiosios universitetų misijos poveikis universitetiniam mokymui: norminių reikalavimų nacionalinèms studijų programoms kaita}

Analizuojant LR studijų kokybės vertinimo centro parengtus dokumentus, kuriuose yra patvirtinami reikalavimai tiek naujų studijų programų rengimui, tiksliau aprašui, tiek jau vykdomų studijų programų analizei ar studijų programų aprašų vertinimui, universitetų studijų veiklos rezultatų praktinio pritaikomumo aspektu, kuris laikytinas esminiu trečiosios universitetų misijos koncepcijos skiriamuoju požymiu, pastebima, kad dokumentuose, rengtuose iki 2010 m., neatsispindi aukštųjų mokyklų bendradarbiavimo su profesine sritimi, socialiniais dalininkais poreikis: 2006 m. patvirtintuose Studiju programos aprašo nuostatuose $e^{36}$ ir 2005 m. patvirtintuose dokumentuose: Naujos studiju programos priemimo ir vertinimo išvadu pateikimo apraše ${ }^{37}$ bei Naujos studiju programos priemimo ir vertinimo išvadu pateikimo tvarkos apraše $e^{38}$, o $2010 \mathrm{~m} .{ }^{39}$, o ypač $2011 \mathrm{~m} .{ }^{40}$ ir $2013 \mathrm{~m} \cdot{ }^{41}$ parengtuose ir patvirtintuose studijų programų aprašuose, studijų programų vertinimą reglamentuojan-

35 Lietuvos aukštojo mokslo (LAM) sistemos plètra 2007-2012 m.: konkurencingumas ir finansavimo modelis [interaktyvus]. 2009 [žiūrèta 2013-07-17]. <http://www.smm.lt/svietimo_bukle/docs/tyrimai/LAM_pletros_pasiulymas_260207.pdf $>$.

36 Studijų programos aprašo nuostatai. Patvirtinta Studijų kokybės vertinimo centro direktoriaus 2006 m. vasario 15 d. ịsakymu Nr. 1-29. Valstybès žinios. 2006, Nr. 24-832.

37 Naujos studijų programos prièmimo ir vertinimo išvadų pateikimo aprašas. Patvirtinta Studijų kokybès vertinimo centro direktoriaus $2005 \mathrm{~m}$. rugpjūčio 5 d. įsakymu Nr. 1-90. Valstybès žinios. 2005, Nr. 97-3696.

38 Ibid.

39 Studijų kokybės vertinimo centro direktoriaus 2010 m. gruodžio 20 d. ịsakymas Nr. 1-01-162 „Dèl vykdomų studijų programų vertinimo metodikos patvirtinimo“. Valstybès žinios. 2010, Nr. 156-7954.

40 Studijų kokybès vertinimo centro direktoriaus $2011 \mathrm{~m}$. lapkričio 28 d. ̣̇sakymas Nr. 1-01157. „Dèl ketinamos vykdyti studijų programos aprašo rengimo, jos išorinio vertinimo ir akreditavimo metodikos patvirtinimo“. Valstybès žinios. 2011, Nr. 147-6925.

41 Dèl ketinamos vykdyti studijų programos aprašo rengimo, jos išorinio vertinimo ir akreditavimo metodikos, patvirtintos Studijų kokybès vertinimo centro direktoriaus $2011 \mathrm{~m}$. lapkričio 28 d. įsakymu Nr. 1-01-157, pakeitimo. Valstybès žinios. 2013, Nr. 91-4565. 
čiuose dokumentuose ịtvirtinama aiški sąsaja su socialiniais dalininkais, profesijos atstovais, akcentuojant aukštosios mokyklos rengiamų specialistų rinkos poreikio formavimą, studijų programos igyvendinimą derinant su profesine sritimi, potencialiais darbdaviais, taip pat ir atliepiant visuomenès poreikius.

Po $2009 \mathrm{~m}$. nacionalinès aukštojo mokslo reformos buvo parengti nauji norminiai dokumentai, kuriuose ịvardyti nauji reikalavimai studijų programoms, ịprasminami studijų programų aprašų, teikiamų vertinimo institucijai, metodikose. Po 2009 m. aukštojo mokslo reformos parengti norminiai dokumentai, pateikiantys reikalavimus studiju programoms, iggyvendinamoms Lietuvos aukštosiose mokyklose, ne tik nurodo tam tikrus reikalavimus studijų programoms, studijų kokybei, bet ir atskleidžia valstybės poziciją ir dèl universitetų studijų misijos igyvendinimo. Specifinių reikalavimų studiju programoms, studijų procesui, susijusių su studijose teikiamų mokslo žinių praktiniu pritaikomumu, praktinio poreikio (rinkos, valstybès, regiono ar pan.) reikšminimu, socialinių partnerių (taip pat ir ükio subjektų) įtrauktimi ị studijų programų rengimą, studijų procesą ryškinimas atskleidžia ir numanomą palankų valstybès požiūrị ị trečiąją universitetų misiją. Greta pateikiamų reikalavimų studijų programų aprašams, apibrèžiama ir studijų programos aprašo paskirtis, kurioje akcentuojamas aprašo taikymas siekiant ,informuoti būsimus studentus apie programos tikslus, programoje numatomus studiju rezultatus, turini, mokymo metodus, vertinima“" (11.1.), bet ir "suteikti informacija studentams apie tai, ka jie privalès žinoti, gebèti, suprasti baigus programa <...>“ (11.2.), „suteikti informacija darbdaviams apie programos studiju rezultatus, studiju turinị ir absolventy kvalifikacija“" (11.3.) (pabraukta autorių), „sukurti prielaidas programos dalyviu ir socialiniu partneriu komunikacijai" (11.4.) (pabraukta autorių) ${ }^{42}$. Šiuose teiginiuose nurodomas ne tik reikalavimas, keliamas aukštosioms mokykloms, dèl informacijos apie studiju programą teikimą tiek studentams, tiek ir kitiems suinteresuotiesiems, bet ir išryškinamas socialinių partnerių ịtraukimas ị studijų programos kūrimą ir ịgyvendinimą, akcentuojant suteikiamos kvalifikacijos atitiktị darbdavių išsakomiems lūkesčiams bei keliamiems reikalavimams atitinkamos kvalifikacijos darbuotojams. Tokiu būdu jau studijų programos aprašo paskirtyje (reikalavimai parengti $2011 \mathrm{~m}$.) yra nurodomas aukštosioms mokykloms keliamas reikalavimas, siejamas su universitetų studijų veiklos rezultatų praktiniu pritaikomumu.

Norminiuose reikalavimuose ketinamoms vykdyti studijų programoms ${ }^{43}$ ịvardijami šie aspektai, ryškinantys universitetų studijų veiklos rezultatų praktinį pritaikomumą:

- studiju programos poreikị pagrindžiantys argumentai atskleidžiami siejant juos su darbo rinkos tyrimais, turimais ištekliais (ypač personalu, kuris gali suteikti tas kompetencijas, kurios atlieptų darbo rinkos poreikius: „pagal programa numatomu rengti specialistu poreiki šalyje ar regione, absolventu galimybes įsidarbinti (6.1.); mokslini ar profesini potenciala vykdyti numatomos krypties studijas (6.2.); turimus ar 
ketinamus pasitelkti išteklius (žmonių, materialiuosius ir metodinius) numatytų studiju formu studijoms vykdyti (mokslininkai ir desstytojai, tinkamai įrengtos auditorijos, meninés kūrybos ir veiklos erdvés, laboratorijos, kompiuteriai su reikiama programine irranga, mokslinès ir profesinès periodikos, naujos literatūros ir (ar) meno küriniu fon-

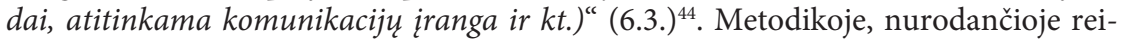
kalavimus ketinamų vykdyti studijų programų aprašui, nurodoma, kad „pagrįsdama programos poreikį, aukštoji mokykla pateikia apibendrintus programos rengejjų, darbdaviu ir kitu socialiniu partneriu, kitu institucijų atliktų tyrimų, apklausų rezultatus ar kitą ketinamų rengti specialistu poreiki ịrodančia informacija“" (16. $)^{45}$.

- studiju programos tikslus ir numatomus rezultatus, akcentuojant studiju programos tikslo pagrịstumą „ketinamų rengti specialistu veiklai keliamais reikalavimais, susietais su asmens, baigusio studijas pagal ta programa, igyjamais studiju rezultatais (žiniomis ir gebejimais)“ (15.1.) ${ }^{46}$, taip pat nurodoma, kad studijų rezultatai studijų programoje turi būti formuluojami atsižvelgiant ị Lietuvos kvalifikacijų sandaros atitinkamo lygio reikalavimus ir teisès aktus, „nustatančius reikalavimus igyjamai (profesinei) kvalifikacijai (jei teikiama)“(15.2. ${ }^{47}$.

Taigi, kaip matyti iš pateikiamos analizès, ketinamų vykdyti studijų programų aprašo reikalavimuose, atliepiančiuose universitetų trečiosios misijos koncepciją, universitetų studijų veiklos rezultatų pritaikomumo reikalavimas didžia dalimi atspindimas per studijų programų poreikio ir studijų rezultatų atitikties darbo rinkos poreikiams pagrindimą.

Kita grupe reikalavimų, susijusių su jau igyvendinamų studijų programų vertinimu, - studijų programų, teikiamų akreditavimui, aprašų reikalavimai, parengti $2010 \mathrm{~m} .{ }^{48}$. Vykdomų studijų programų vertinimo ir akreditavimo metodikoje yra ryškinami tokie mokslo žinių teikiamų studijų procese praktinio pritaikomumo reikalavimai (reikšminami trečiosios universitetų misijos koncepcijoje):

- rengiant savianalizę (dokumento, kurio pagrindu vykdomas studijų programos vertinimas) keliamas reikalavimas ị darbo grupę ịtraukti ne tik administracijos darbuotojus, desstytojus, studentus, bet ir socialinius dalininkus (20.); nurodoma, kad savianalizèje pateikiamus rezultatus rekomenduojama aptarti bendruomenèje (21.), taip pat ị susitikimus su vertintojais įtraukti ịvairius socialinius dalininkus $(36,37)^{49}$;

- programos tikslas ir numatomi studijų rezultatai turi būti „pagristi akademiniais ir (ar) profesiniais reikalavimais, visuomenès ir darbo rinkos poreikiais“ $(58.2 \text {. })^{50}$, o „programos turinys atitinka naujausius mokslo, meno ir technologiju pasiekimus" (59.6.) ${ }^{51}$;

$\begin{array}{ll}44 & \text { Supra note } 40 . \\ 45 & \text { Ibid. } \\ 46 & \text { Ibid. } \\ 47 & \text { Ibid. } \\ 48 & \text { Supra note } 39 . \\ 49 & \text { Ibid. } \\ 50 & \text { Ibid. } \\ 51 & \text { Ibid. }\end{array}$


- pristatant aukštosios mokyklos turimus materialiuosius išteklius, būtinus studijų programos ịgyvendinimui, turi būti ịrodoma, jog ,aukštoji mokykla turi tinkama baze praktikoms" $(61.3 .)^{52}$.

Apibendrinant reikalavimus vykdomų studijų programų aprašams, kurių pagrindu yra vykdomas studijų programos ekspertinis vertinimas ir akreditavimas, pastebima, kad skirtingai nuo reikalavimų, išdèstytų ketinamoms vykdyti studijų programoms, vykdomų studijų programų apraše turi būti aptariama daugiau dalykų, sietinų su universitetų trečiosios misijos koncepcija: darbo rinkos poreikiai ir programos atitinkamų tikslų ir rezultatų formulavimas yra papildomi reikalavimais dèl atliekamų tyrimų atitikties vykdomai studijų programai (kartu ir aktualiais atitinkamai profesinei veiklos sričiai), taip pat nurodomas profesinių praktikų bazių skaičiaus adekvatumas išsikeltiems studijų rezultatams. Šie aspektai yra susiję su aktyviu socialinių dalininkų, potencialių (esamų) darbdavių ịtraukimu ị studijų procesą, taip pat siekiu nustatyti personalo atliekamų tyrimų sąsajas su studijų programos ar atitinkamo déstomo dalyko (veiklos, profesine) sritimi.

Trečiasis aspektas, kuris svarbus analizuojant studijų programoms keliamus reikalavimus, susijusius su universitetų trečiosios misijos koncepcija, - reikalavimai, ¡ kuriuos atsižvelgdami studijų programas vertina ekspertai. Reikalavimai studijų programos analizei yra išdèstyti atitinkamuose $2009 \mathrm{~m}$. ir $2010 \mathrm{~m}$. dokumentuose dèl „Vykdomų studijų programų vertinimo metodikos patvirtinimo" ${ }^{53}$ (2010) ir „Studijų programų išorinio vertinimo ir akreditavimo tvarkos aprašo patvirtinimo" (2009). Analizuojant aspektus, pagal kuriuos vertinamos studijų programos, matyti, kad studijų programos analizè siejama su:

- studijų programos tikslu ir numatomais rezultatais, kurie turètų remtis "profesinés veiklos pasaulio tyrimu rezultatais, pagrindžiančiais numatomu studiju rezultatu aktualuma“" (95.4. $)^{54}$, taip pat ịvardijant „profesinès veiklos sritis, kurioms rengiami specialistai pagal analizuojama programa ir ju sasajas su programos studiju rezultatais" (95.5.) ${ }^{55}$;

- studijų eiga ir jos vertinimu, kuriam pagristi yra siūloma išnagrinèti „duomenis apie absolventu skaičius ir specialistu poreikị (esama ir (ar) numatoma) nurodant specialistu poreikio duomenu šaltinius“ (106.7. ${ }^{56}$, , „duomenis, per kokị laiką absolventai isitvirtina darbo rinkoje ${ }^{{ }^{57}}(106.8$.$) , „duomenis apie programa baigusius absolventus,$ ju issidarbinima apskritai ir ịsidarbinima pagal igyta specialybę (išsilavinima) (iskaitant įsidarbinusius iki studiju baigimo)“(106.9. $)^{58}$.

$\begin{array}{ll}52 & \text { Supra note } 39 . \\ 53 & \text { Ibid } \\ 54 & \text { Supra note } 40 . \\ 55 & \text { Ibid. } \\ 56 & \text { Ibid. } \\ 57 & \text { Ibid. } \\ 58 & \text { Ibid. }\end{array}$


- „Ketinamų vykdyti studijų programų aprašo rengimo, jos išorinio vertinimo ir akreditavimo metodikos patvirtinimo“ $(2011,2013){ }^{59},{ }^{60}$ dokumente ryškinami kiek kiti studijų programos išorinio vertinimo kriterijai: „programos tikslai ir numatomi studiju rezultatai pagristi akademiniais ir (ar) profesiniais reikalavimais, visuomenes ir darbo rinkos poreikiais“ (53.2.); "programos turinys atitinka naujausius mokslo, meno ar technologiju pasiekimus“ (54.5.); „i programos vertinimo ir tobulinimo procesus numatomi ịtraukti socialiniai dalininkai“ (58.2) ${ }^{61}$. Taip studiju programų vertinimas yra papildomas studijų programos turiniui keliamais reikalavimais atitikti naujausius mokslo, technologijų ir meno pasiekimus.

1 lentelè. Universitetų trečiosios misijos koncepcijos raiškų analizė Lietuvos studijų kokybès vertinimo centro patvirtintuose norminiuose reikalavimuose studijų programoms ir jų aprašams iki 2009 m. nacionalinès aukštojo mokslo reformos ir po jos

\begin{tabular}{|l|c|c|c|}
\hline & $\begin{array}{c}\text { Reikalavimai } \\
\text { ketinamų } \\
\text { vykdyti studijų } \\
\text { programų } \\
\text { aprašams }\end{array}$ & $\begin{array}{c}\text { Reikalavimai } \\
\text { vykdomų } \\
\text { studijų } \\
\text { programų } \\
\text { savianalizės } \\
\text { aprašui }\end{array}$ & $\begin{array}{c}\text { Studijų } \\
\text { programų } \\
\text { vertinimo } \\
\text { principai }\end{array}$ \\
\hline $\begin{array}{l}\text { Programos tikslai ir numatomi } \\
\text { studijų rezultatai }\end{array}$ & + & + & + \\
\hline Programos sandara & $+/-$ & + & + \\
\hline Personalas & $+/-$ & + & + \\
\hline Materialieji ištekliai & + & + \\
\hline Studijų eiga ir jos vertinimas & + & + \\
\hline Programos vadyba & & + & + \\
\hline
\end{tabular}

Norminių dokumentų analizė atskleidè, kad galima rasti numanomų bendrų su socialinių dalininkų ịtraukimu ị studijų procesą susijusių dalykų tiek 2005 m., 2006 m., tiek 2010 m., 2011m. ir 2013 m. dokumentuose. Tai - reikalavimas pagristi studijų programos poreiki, kuris, galima manyti, kad 2006 m. dokumente Studiju programos aprašo nuostatuose ${ }^{62}$ pagal nutylejimą gali būti siejamas su darbo rinkos poreikiu, o naujesniuose (2010 m., 2011m., 2013 m.) dokumentuose yra išplètojamas, ịtraukiant teiginius dèl studijų programos atliepimo darbo rinkos poreikiams, komunikacijos su darbdaviais ir socialiniais dalininkais. Atliktas tyrimas parode 
akivaizdžiai padidèjusį dèmesị studijų veiklos rezultatų praktiniam pritaikomumui po $2009 \mathrm{~m}$. nacionalinès aukštojo mokslo reformos. Tačiau atlikus tyrimą pastebèta ir tai, kad Lietuvoje studijų programų vertinimui ir akreditavimui keliami kiek kiti reikalavimai, susiję su praktiniu universitetų studijų misijos įgyvendinimo aspektu nei ketinamų vykdyti ar jau igyvendinamų studijų programų aprašuose nurodomi aspektai. Studijų programų vertinimas ir akreditavimas siejamas ir su demesio atkreipimu ị socialinių dalininkų vaidmenį, darbo rinkos ir profesinès veiklos srities aktualumas yra reikšminamas ne tik studijų programos tikslo ir numatomų studijų rezultatų apibrěžtyje, bet ir studijų eigos apraše. Tai, kad dokumentuose, pateikiant reikalavimus studijų programos aprašui ir studijų programos vertinimui akcentuojami skirtingi aspektai, leidžia teigti, kad egzistuoja tam tikra neatitiktis tarp norminiu reikalavimų studijų programos aprašui ir kriterijų, pagal kuriuos yra vertinamos studijų programos.

\section{Išvados}

Kintančios veiklos sąlygos turi visuminị poveikị universitetų veiklai, tradicinėms universitetų funkcijoms. Universitetų veiklos kaita paskatino su tradicinemis universitetų funkcijomis susijusios mokslo žinių sklaidos pokyčius - tradicinę mokslo žinių sklaidą keičia, papildo mokslo rezultatų sklaidos per jų praktinį pritaikymą procesai. Mokslininkai, vertindami universitetuose vykstančius pokyčius, teigia besiformuojant trečiąją universitetų misiją, kuriai būdingas universitetų verslumas, universitetų teikiamos praktinès naudos visuomenei reikšminimas.

Trečiosios universitetų misijos koncepcijoje reikšminama praktinès naudos visuomenei svarba keičia tiek mokslinių tyrimų, tiek studijų kaip mokslo žinių sklaidos procesus bei universitetų veikloje formuoja savitas veiklos sritis, siejamas tiek su ekonominès, tiek su socialinès, kultūrinès ar kitokios naudos visuomenei, bendruomenei, regionui teikimo poreikiu.

Trečiosios universitetų misijos teorinè prieiga taikytina ir aiškinant Europos aukštojo mokslo sistemose vykstančius pokyčius, siejamus su tuo, kad tradicinè europinė aukštojo mokslo orientacija ị visuomenès socialines, kultūrines reikmes, aukštojo mokslo kaip valstybès vykdomos socialinès politikos, užtikrinamos viešaisiais ištekliais, suvoktis yra keičiama rinkos ideologijos, neoliberalizmu argumentuojamos naujosios viešosios vadybos taikymo aukštojo mokslo sistemai. Šią išvadą pagrindžia tai, kad naujoji viešoji vadyba yra sietina su universitetų verslumo skatinimu bei su siekiu padidinti universitetų veiklos rezultatų praktinị pritaikomą. Todèl greta tradicinès europinès aukštojo mokslo sistemos orientacijos ị visuomenès socialinius poreikius, aukštojo mokslo kaip viešojo gèrio suvokties formuojasi rinkos prieigos požiūris, universitetų visuomenei teikiamos praktinès naudos reikšminimas.

Teorinis tyrimas patvirtina prielaidą, kad 2009 m. nacionalinè Lietuvos aukštojo mokslo sistemos reforma, vykdoma neoliberalizmo dvasia, pakeitusi aukštojo mokslo sistemos finansavimą, paskatinusį aukštųjų mokyklų konkurenciją, sudariusi sąly- 
gas jų verslumui, taip pat yra grindžiama praktinio aukštojo mokslo sistemos veiklos rezultatų (tiek mokslo tyrimų, tik studijų srityse) naudojimo svarbos reikšminimu.

Atliktas kokybinis norminių dokumentų turinio tyrimas, dokumentų nuostatų palyginimas leido pastebėti, kad Lietuvoje veikiančių aukštųjų mokyklų ryšiai ir galimas bendradarbiavimas su profesinès srities atstovais, darbdaviais ir socialiniais dalininkais tik iš dalies yra matomas norminiuose dokumentuose, kuriuose reglamentuojami studijų programų aprašai iki nacionalinės aukštojo mokslo reformos; ženklus visuomenès intereso ir darbdavių ịtraukimo ị studijų procesą ịtvirtinimas dokumentuose pastebimas tik dokumentuose, priimtuose po $2009 \mathrm{~m}$. nacionalinès aukštojo mokslo reformos.

Tyrimas atskleidè, kad Lietuvoje ketinamų vykdyti ar jau igyvendinamų studijų programų aprašams ir studijų programų vertinimui ir akreditavimui keliami kiek skirtingi norminiai reikalavimai, susiję su universitetų studijų misijos igyvendinimo praktinès naudos aspektu. Vertinant ir akredituojant studijų programas yra dar labiau reikšminamas studijų rezultatų praktinio pritaikomumo poreikis, nes norminiuose reikalavimuose studijų programų vertinimui ir akreditavimui dar labiau išryškinamas socialinių dalininkų vaidmuo, santykis su darbo rinka ir profesine sritimi yra nurodomas ne tik studijų programos tikslo ir numatomų studijų rezultatų apibrèžtyje, bet ir studijų eigos apraše.

\section{Literatūra}

Altbach, P. G. The complex roles of universities in the period of globalization. Higher education in the world. 2008, 3.

Altbach, P. G.; Knight, J. The internationalization of higher education: Motivations and realities. Journal of studies in International education. 2007, 11(3-4).

Arbo, P.; Benneworth, P. Understanding the regional contribution of higher education institutions: A literature review. A research report prepared for the OECD Institutional Management in Higher Education Programme „, The contribution of higher education to regional development“. OECD Paris, 2008.

Archer, W.; Davison, J. Graduate employability: What do employers think and want? The Council for Industry and Higher Education (CIHE) [interaktyvus]. London, 2008 [žiūrèta 2014-07-19]. <www.cihe-uk.com/ docs/PUBS/0802Grademployability. pdf $>$.

Benneworth, P.; Jongbloed, B. W. Who matters to universities? A stakeholder perspective on humanities, arts and social sciences valorization. Higher Education. 2010, 59(5).

Biomedicinos mokslų srities apžvalga. SKVC [interaktyvus]. [žiūrèta 201410-16]. <http://www.skvc.lt/files/SVS/ biomedicinos_mokslu_apzvalga.pdf $>$.

Breznitz, S. M.; Feldman, M. P. The larger role of the university in economic development: introduction to the special issue. The Journal of Technology Transfer. 2012, 37(2).

Butkus, E.; Viliūnas, G. Universitetų valdymo reforma Europos šalyse. Mokslas ir technika. 2006, 5. 
Charles, D. Universities as key knowledge infrastructures in regional innovation systems. Innovation: the European journal of social science research. 2006, 19(1).

Chatterton, P.; Goddard, J. The response of higher education institutions to regional needs. European Journal of Education. 2000, 35(4).

Chatterton, P.; Goddard, J. The response of HEIs to regional needs. Economic Geography of Higher Education. NY: Routledge, 2003.

Clark, B. R. Creating Entrepreneurial Universities: Organizational Pathways of Transformation. Issues in Higher Education. NY, 1998.

De Zilwa, D. Using entrepreneurial activities as a means of survival: Investigating the processes used by Australian universities to diversify their revenue streams. Higher Education. 2005, 50(3).

Dzemyda, I.; Babravičius, J. Naujosios viešosios vadybos elementai ir „studijų krepšelio "modelio diegimas Lietuvoje. Viešoji politika ir administravimas. 2012, 11 (2).

Fernández-Esquinas, M.; Pinto, $\mathrm{H}$. The role of the universityin Urban regeneration: reframing the analytical approach [interaktyvus]. 2011 [žiūrèta 2014-10-16]. <http://works.bepress. com/manuel_fernandez_esquinas/37>.

Fizinių mokslų srities apžvalga. SKVC [interaktyvus]. [žiūrèta 2014-10-16]. <http://www.skvc.lt/files/SVS/fiziniu_ mokslu_apzvalga.pdf $>$.

Gibb, A.; Haskins, G.; Robertson, I. Leading the entrepreneurial university: Meeting the entrepreneurial development needs of higher education institutions. Universities in Change, NewYork: Springer, 2013.

Guerrero, M.; Urbano, D. The development of an entrepreneurial university. The
Journal of Technology Transfer. 2012, 37(1).

Hannon, P. D. Why is the Entrepreneurial University Important? Journal of Innovation Management. 2013, 1(2).

Howard, J.; Sharma, A. Universities Third Mission: Community Engagement, B-HERT (Business/Higher Education Round Table) Position Paper [interaktyvus]. June 2006, 11 [žiūrèta 2014-10-09]. <http://www.bhert.com/ publications/position-papers/B-HERT PositionPaper11.pdf $>$.

Kaip organizuojamas studijų programų rengimas ir vertinimas: Lietuvos Respublikos valstybès kontrolè valstybinio audito ataskaita [interaktyvus]. 2012 m. spalio 1 d. Nr. VA-P-50-1-12 [žiūrèta 2014-10-14]. <www.vkontrole.lt/ failas.aspx? $\mathrm{id}=2733>$.

Landabaso, M.; Oughton, C.; Morgan, $\mathrm{K}$. Learning regions in Europe: theory, policy and practice through the risk experience. 3rd International Conference on Technology and Innovation Policy: Global knowledge Partnerships, Creating value forthe 21 Century. Austin, USA (August 30 -September 2) [interaktyvus]. 1999 [žiūrèta 2014-07-07]. <http://www. deu.edu.tr/userweb/sedef.akgungor/ dosyalar/learning\%20region2.pdf $>$.

Leitch, S. Prosperity for all in the global economy-world class skills: final report. The Stationery Office, 2006.

Leydesdorff, L.; Meyer, M. The Triple Helix of University-Industry-Government Relations: Introduction to the Topical Issue. Scientometrics. 2003, 58(2).

Lietuvos aukštojo mokslo (LAM) sistemos pletra 2007-2012 m.: konkurencingumas ir finansavimo modelis [interaktyvus]. 2009 [žiūrèta 2013-07-17]. <http://www.smm.lt/ svietimo_bukle/docs/tyrimai/LAM_ pletros_pasiulymas_260207.pdf> 
Maskell, D.; Robinson, I. The New Idea of a University. Imprint academic, 2002.

Mittelstadt, A.; Cerri, F. Fostering Entrepreneurship for Innovation. OECD STI Working Paper 2008/5. Technology Incubators: Nurturing Small Firms. Paris: OECD Publishing, 2008.

Mokslo ir studijų būklès apžvalga [interaktyvus]. 2009 [žiūrèta 201407-17]. <http://www.mosta.lt/ images/documents/stebesena/bukles_ apzvalga/mokslas_ir_studijos_2009. pdf $>$.

Mokslo ir studijų reforma: pristatymas [interaktyvus]. 2008 [žiūrèta 201407-17]. <http://www.smm.lt/msr/ docs/Informacija_mokslo_ir_studiju_ reforma.pdf $>$.

Molas-Gallart, J.; Castro-Martínez, E. Ambiguity and conflicting the development of 'ThirdMission' indicators. Research Evaluation. 2007, 16(4)

Owen-Smith, J; Riccaboni, M.; Pammolli, F.; Powell, W. W. A comparison of US and European universityindustry relations in the life sciences. Management science. 2002, 48(1).

Pileičikienè, N.; Pukelis, K. Aukštųjų mokyklų absolventų išsiugdytų bendrųjų kompetentingumų ir darbo rinkos poreikių atitiktis. Aukštojo mokslo kokybe. 2012, 9.

Polt, W.; Gassler, H.; Schibany, A.; Rammer, C.; Schartinger, D. Benchmarking industry-science relations: the role of fraze work conditions. Science and public policy. 2001, 28(4).

Progress in higher education reform across Europe. Governance reform. Volume 1: executive summary and main report. Center for Higher Education Policy Studies. Unassigned, [interaktyvus]. 2010 [žiūrèta 2014-0317]. <http://ec.europa.eu/education/ higher-education/doc/governance/ sum_en.pdf $>$.

Progress in higher education reform actos Europe. Funding reform. Volume 1: Executive summary and main report. Center for Higher Education Policy Studies. Unassigned, [interaktyvus]. 2010 [žiūrèta 2014=03-17]. <http:// ec.europa.eu/education/higher-edu cation/doc/funding/sum_en.pdf $>$.

Ramakrishnan, K.; Yasin, N. M. Higher learning institution-industry collaboration: A necessity to improve teaching and learning process. Computer Science and Education (ICCSE), 2011 6th International Conference. 2011.

Serafinas, D.; Ruževičius, J. Aukštųjų mokyklų veiklos tobulinimo pokyčių kontekste ižvalgos. Ekonomika ir vadyba. 2009, 14.

Shattock, M. European universities for entrepreneurship: Their role in the Europe of knowledge the theoretical context. Higher Education Management and Policy. 2005, 17(3).

Socialinių mokslų srities apžvalga. SKVC [interaktyvus]. [žiūrèta 2014-10-16]. <http://www.skvc.lt/files/SVS/socialiniu_mokslu_apzvalga.pdf $>$.

Želvys, R. Studento krepšelis: pirmieji eksperimento rezultatai. Pedagogika. 2009, 96.

Tyrimo šaltiniai:

Dèl Studijų kokybès vertinimo centro direktoriaus $2010 \mathrm{~m}$. gruodžio $20 \mathrm{~d}$. ịsakymo Nr. 1-01-162 „Dèl Vykdomų studijų programų vertinimo metodikos patvirtinimo" pakeitimo. Valstybes žinios. 2013, Nr. 86-4327.

Dèl ketinamos vykdyti studijų programos aprašo rengimo, jos išorinio vertinimo ir akreditavimo metodikos, patvirtintos Studijų kokybès vertinimo centro direktoriaus $2011 \mathrm{~m}$. lapkričio 28 d. ìsakymu Nr. 1-01-157, pakeitimo Valstybès žinios. 2013, Nr. 91-4565. 
Dèl ketinamos vykdyti studijų programos aprašo rengimo, jos išorinio vertinimo ir akreditavimo metodikos, patvirtintos Studijų kokybès vertinimo centro direktoriaus $2011 \mathrm{~m}$. lapkričio 28 d. įsakymu Nr. 1-01-157, pakeitimo. Valstybès žinios. 2013, Nr. 49-2469

Naujos studijų programos priemimo ir vertinimo išvadų pateikimo aprašas. Patvirtinta Studijų kokybės vertinimo centro direktoriaus $2005 \mathrm{~m}$. rugpjūčio 5 d. ìsakymu Nr. 1-90. Valstybés žinios. 2005, Nr. 97-3696.

Studiju kokybès vertinimo centro direktoriaus $2010 \mathrm{~m}$. gruodžio $20 \mathrm{~d}$. ịsakymas Nr. 1-01-162 „Dèl vykdomų stu- dijų programų vertinimo metodikos patvirtinimo“. Valstybès žinios. 2010, Nr. 156-7954.

Studijų kokybès vertinimo centro direktoriaus $2011 \mathrm{~m}$. lapkričio $28 \mathrm{~d}$. įsakymas Nr. 1-01-157 „Dèl ketinamos vykdyti studijų programos aprašo rengimo, jos išorinio vertinimo ir akreditavimo metodikos patvirtinimo“. Valstybès žinios. 2011, Nr. 147-6925.

Studijų programos aprašo nuostatai. $\mathrm{Pa}-$ tvirtinta Studijų kokybès vertinimo centro direktoriaus $2006 \mathrm{~m}$. vasario $15 \mathrm{~d}$. įsakymu Nr. 1-29. Valstybès žinios. 2006, Nr. 24-832.

\title{
IMPACT OF UNIVERSITIES' THIRD MISSION TO DISSEMINATION AND INTEGRATION OF SCIENTIFIC KNOWLEDGE IN STUDY PROCESS IN UNIVERSITIES
}

\author{
Marija Stonkienè, Renata Matkevičienė \\ Vilnius University, Lithuania
}

\begin{abstract}
Summary. The paper discusses the impact of development of knowledge economy to the universities' activities, suggesting that providing the status of the product to the knowledge as the main field of activities of universities change not only the operating conditions of universities, but at the same time stress the meaningful contribution of universities to economic growth and social development. Changing conditions for delivery of universities' practices encourage universities to become a part of a knowledge network as innovation agents to enhance cooperation with industry. Declining public resources, growing competition in the dissemination of knowledge in the scientific field stimulate universities' entrepreneurship, application of their performance and results. All this justifies the idea of transformation of universities' mission: from traditional universities' functions, such as delivery of academic studies and scientific research, to dissemination of scientific knowledge, a traditional dissemination of scientific knowledge changes has been supplemented by application of scientific knowledge in collaboration with industry or for wellbeing of society. Contemporary changes taking place in universities consolidate the formation of the third mission of universities. The third mission of universities is based on the concept of an entrepreneurial university and the prominence of provided practical benefits of the universities' activities. According to a theoretical approach, the
\end{abstract}


third mission of universities is understood through the changes in the higher education systems associated with the fact that the traditional European higher education as a part of state-led social policy with a focus on meeting the social, cultural needs of society, creation of public resources changes because of growing importance of market ideology, neoliberalism, that reasons implementation of new public management in higher education. New public management stresses changing performance of universities toward practical applicability of scientific knowledge and meeting not only social needs of society, but market needs, as well.

The article states that in 2009, when reform of Lithuanian national system of higher education made some corrections in the system of higher education funding, universities spurring competition created conditions for entrepreneurial universities. Changes in the system of higher education also made an impact to requirements of application of scientific results in study process, as well as meeting the needs and integration of various stakeholders into universities' activities.

The aim of the present research is to assess whether the reform of Lithuanian national higher education that started in 2009 had a mission to stress practical application of scientific knowledge, response to the market needs, and that are declared in official documents are integrated into requirements for national study programs (for preparation of documentation of newly created study programs and for the valuation of study programs). The task of the research is to analyse changes in national requirements and their correspondence with the main goals of reform of national higher education system.

Regulatory documents were analyzed using qualitative content analysis and comparative methods. It was found that after 2009 Lithuanian national higher education reforms in the updated regulatory requirements for study programs there was manifested the requirement to provide arguments that showed accordance of study program with public interest and the employers' needs. The research showed an increase of importance in focus on practical adaptability after 2009 national higher education reforms: in regulatory documents that existed till 2009 there were no intentions of integration of study process with stakeholders' involvement that led toward meeting the needs of labor market and society. The study also revealed that in Lithuanian regulatory requirements for study programs - regulatory documents for proposal of newly developed study programs and in criteria for evaluation and accreditation of study programs - there has already been implemented a requirement of fulfilling practical applicability of the results and meeting the needs of employers that goes in a line with the third mission of universities stressing the practical benefit aspect of study programs. In the regulatory requirements for evaluation and accreditation of study programs, there are more substantially presented requirements for fulfilling practical applicability of study results in relation with needs of labor market and this requirement goes with a highlight of the role of the social partners in development and implementation of study program.

Keywords: university, dissemination of scientific knowledge, universities' third mission, national reform of higher education in 2009, studies, study programs, regulation. 
Marija Stonkienè, Vilniaus universiteto Komunikacijos fakulteto Informacijos ir komunikacijos instituto profesoré, socialinių mokslų daktarè. Mokslinių tyrimų sritys: mokslo komunikacija, viešoji komunikacija, intelektinès nuosavybès teise, informacijos teisè.

Marija Stonkienè, Doctor of Social Sciences, Vilnius University, Faculty of Communication, Institute of Information and Communication, Professor. Research interests: science communication, public communication, intellectual property law, information law.

Renata Matkevičienè, Vilniaus universiteto Komunikacijos fakulteto Informacijos ir komunikacijos instituto docentė, socialinių mokslų daktarè. Mokslinių tyrimų sritys: mokslo komunikacija, socialinė atsakomybė, politikos komunikacija.

Renata Matkevičienè, Vilnius University, Faculty of Communication, Institute of Information and Communication, Doctor of Social Sciences, Assoc. Professor. Research interests: science communication, social responsibility, political communication. 